\title{
Multinationals and Interdependence in Internationalisation Processes ${ }^{(1)}$
}

\author{
Sérgio Fernando Loureiro Rezende
}

\begin{abstract}
ResUMO
Trata-se, neste artigo, de interdependência e processos de internacionalização de multinacionais; um assunto pouco estudado na literatura de internacionalização (ver, por exemplo, Bell \& Young, 1998; Holm et al., 1995). Baseado em revisão de literatura sobre modelos comportamentais de internacionalização, inicialmente sugere-se, neste artigo, que multinacionais podem ser entendidas como sistemas do tipo loosely coupled, nos quais a independência e a interdependência de suas operações moldam como essas firmas organizam atividades nos diversos mercados que operam. Posteriormente, modela-se o processo de internacionalização de multinacionais por meio de três dimensões que caracterizam o seu padrão evolutivo - uniformidade, direção e ritmo, e sugere-se três hipóteses sobre a relação entre essas dimensões e interdependência. A relação é considerada negativa, ou seja, em condições ceteris paribus, interdependência é negativamente relacionada à uniformidade, à direção e ao ritmo de processos de internacionalização. Conclui-se o artigo, chamando atenção para o fato de que a internacionalização de multinacionais resulta de uma intricada combinação de inúmeros processos de internacionalização que são simultaneamente independentes e interdependentes e que, portanto, evoluem em diversos contextos espaciais e temporais da rede da multinacional.
\end{abstract}

Palavras-chave: internacionalização; multinacionais; interdependência.

\begin{abstract}
This article deals with interdependence and the internationalisation process of multinationals (MNCs); a topic that has received scarce attention in the literature (e.g. Bell \& Young, 1998; Holm et al., 1995). By reviewing the literature on behavioural models of internationalisation, initially, the article suggests that MNCs should be regarded as loosely coupled systems in which independence and interdependence of operations shape how MNCs evolve and organise activities across borders. Subsequently, the article models the internationalisation process of MNCs by highlighting three dimensions that characterise their pattern of evolution - uniformity, direction and rhythm, and lays out three hypotheses on the relationship between these dimensions and interdependence. The direction of the relationship is suggested to be negative, i.e., other things being equal, interdependence is negatively related to uniformity, direction and the rhythm of the internationalisation processes. The article concludes by claiming that the internationalisation of MNCs results from an intricate combination of independent, yet interdependent, internationalisation processes that evolve in various spatial and temporal contexts within the MNC network.
\end{abstract}

Key words: internationalization; multinationals; interdependence. 


\section{INTRODUCTION}

Behavioural models of internationalisation are concerned with the processes as well as the outcomes of international expansion (Aaharoni, 1966; Johanson \& Vahlne, 1977). A focus on process rather than the mix of variables that produce particular outcomes means that internationalisation must be understood in the context of the paths undertaken by firms to reach their current international status (Vermeulen \& Barkema, 2002).

The behavioural programme research on internationalisation, of which the Uppsala model is a well known offspring, can be broadly characterised as follows. First, a firm undergoes a sequential process of expansion starting from psychically closer countries in order to avoid uncertainty and minimise risks (Cyert \& March, 1963; Johanson \& Wiedersheim-Paul, 1975). It is suggested that the internationalisation process of the firm results from the interplay between knowledge of and market commitment to a particular foreign market (Johanson $\&$ Vahlne, 1977). Secondly, because a firm's absorptive capacity usually expands incrementally (Cohen \& Levinthal, 1990), internationalisation processes are often viewed as slow and gradual (Johanson \& Vahlne, 1977).

Since it was introduced, the Uppsala model has sparked off a number of studies aimed at examining its theoretical assumptions (e.g. Andersen, 1993; Casson, 1994; Forsgren, 2002) and test it in various spatial and temporal contexts (e.g. Andersen, 1997; Hedlund \& Kverneland, 1993; Sullivan \& Bauerschmidt, 1990). One particular argument of interest to this article is the notion that the Uppsala model pays little attention to the internationalisation processes of multinationals (henceforth MNCs) (Forsgren, 1989, 2002), a point acknowledged by the model's progenitors (Johanson \& Vahlne, 1990). More specifically, the Uppsala model does not take into account the fact that knowledge in internationalisation processes is not only created by the interplay between the subsidiary and external actors such as buyers and suppliers embedded in the host country in which the affiliate is established, but can also be accessed through sister subsidiaries and external actors located elsewhere in the MNC network (Holm et al., 1995) (2) In other words, the model does not consider that there may be simultaneous internationalisation processes within the MNC network that are contingent on each other in certain spatial and temporal contexts. According to Johanson and Vahlne (1990, p. 15), "this interdependence between markets can be expected to have a strong impact on the internationalisation of the firm". 
The aim of this article is to look at the effects of the interdependence of internationalisation processes within the MNC network on their pattern of evolution. Our reasoning is that a MNC can be conceptualised as a loosely coupled system in which a number of internationalisation processes co-evolve in different, yet overlapping, networks (Mattsson, 1998). These processes can be simultaneously independent and interdependent in the sense that they can intersect and exert influences on each other across spatial and temporal contexts.

We argue that this view can explain different outcomes from those suggested by the Uppsala model in terms of three dimensions of the pattern of evolution of internationalisation processes: uniformity, direction and rhythm. Following recent attempts to formulate dimensions of internationalisation (Hohenthal et al., 2003; Vermeulen \& Barkema, 2002), we advance three hypotheses on the impact of interdependence of internationalisation processes on their pattern of evolution. While the Uppsala model concentrates on processes that rarely oscillate in terms of uniformity and direction, our view leaves room for understanding less stable internationalisation processes, i.e. those that are less uniform and change direction in often unpredictable ways. In addition, we consider a dimension overlooked by the Uppsala model: rhythm (Vermeulen \& Barkema, 2002). We suggest that the internationalisation processes that exhibit higher levels of interdependence do not tend to follow a rhythmic pattern.

Although some scholars have argued that the understanding of the internationalisation process of MNCs is critical to furthering our knowledge of the internationalisation of the firm (e.g. Bell \& Young, 1998; Chang \& Rosenweig, 2001; Holm et al., 1995), surprisingly little research has examined the effects of interdependence of internationalisation processes. To the best of our knowledge, the only empirical study that touches upon this issue is Chang and Rosenweig (1998a). The authors analyse the evolution of Sony's American subsidiary by focusing on the actors that influenced this process and argue that not only was the American subsidiary's development dependent on the actors embedded in the United States, but also on other actors within the Sony group.

This article is structured as follows. In the first section, we review the literature on the internationalisation process that follows the lead of Johanson and Vahlne's (1977) seminal article. Although there has been a plethora of studies examining empirical manifestations of the Uppsala model, little research has looked at what Johanson and Vahlne (1990) regard as one of the model's Achilles' heels: interdependence between markets and its effects on the internationalisation of the firm. In the second section, we argue that the conceptualising of the MNC as a loosely coupled system provides a solid foundation for addressing the interdependence of internationalisation processes. Our reasoning is that actors 
embedded in the same MNC network follow their own internationalisation processes (e.g. Birkinshaw, 1997; Forsgren et al., 1992) that are simultaneously independent and interdependent across various spatial and temporal contexts. In the third section, we lay out the theoretical model and three hypotheses on the impact of interdependence of internationalisation processes on their uniformity, direction and rhythm. The article concludes by outlining the implications of this view and advancing suggestions for further research on the internationalisation of the firm.

\section{The Uppsala Model and the Internationalisation of MNCs}

In their recent account of the historical evolution of the Uppsala model, Johanson and Vahlne (2003) claim that a new and more realistic picture of the internationalisation of the firm emerged from the research carried out at Uppsala. Rather than seeing internationalisation as the outcome of a rational decisionmaking process through which the firm draws on marketing research and selects an optimal governance form, the model stresses that the internationalisation of the firm is a process strongly dependent on experiential knowledge (Blomstermo \& Sharma, 2003).

In this sense, the model identified a single mechanism that could explain the decision to invest resources in a foreign market over time regardless of the governance form selected by the firm (Johanson \& Vahlne, 2003), i.e., the selfreinforcing mechanism of knowledge development (Eriksson et al., 2000; Johanson $\&$ Vahlne, 1977). To put it differently, over twenty-five years ago the model drew attention to issues that are currently at the top of the research agenda of international business scholars: learning and knowledge development in internationalisation processes (e.g. Blomstermo \& Sharma, 2003; Hadjikhani \& Johanson, 2002; Havila et al., 2002).

Unsurprisingly, the Uppsala model has sparked off a fierce debate amongst scholars. On the one hand, a number of studies found strong support for the model. For example, the idea of gradualism and sequential moves in foreign markets is supported by research carried out by Juul and Walters (1987), Grael and Rocha (1988), Calof (1995), Chang (1995) and Chang and Rosenweig (1998b). Other studies have confirmed that experiential knowledge plays a pivotal role in the internationalisation of the firm (Calof \& Beamish, 1995; Eriksson et al., 1997, 2000; Hadley \& Wilson, 2003; Pedersen \& Petersen, 1998). 
One the other hand, a series of criticisms has been addressed to either the theoretical assumptions or operationalisation of the model. The case of the former, Andersen (1993) contends that the relationship between market knowledge and market commitment is not straightforward. The fact that the firm evolves in the international arena by gradually committing resources to a particular foreign market can be explained by factors other than market knowledge (Petersen \& Pedersen, 1997). Forsgren (2002) casts doubt on the relationship between experiential knowledge and incremental behaviour by claiming that the relationship between them is negative rather than positive. The more the firm learns about the foreign market where it operates, the more it reduces the perceived uncertainty about it. As a result, the firm will be more confident to make larger steps in international markets. In addition, Forsgren (2002) proposes that firms can acquire knowledge not only through experience, but from imitation, search and the acquisition of foreign firms. Casson (1994) and Buckley et al. (2002) advocate that the Uppsala model is more adequate for analysing internationalisation processes through which the firm reaps sizeable economies of scope derived from learning. This corresponds to cases in which, on the one hand, the home and the foreign markets are substantially different and, on the other, the foreign markets are culturally similar.

In relation to the operational level of the model, the concept of the establishment chain has been questioned by authors who associate the model with the earlier work of Johanson and Wiedersheim-Paul (1975). These studies contend that firms can follow a number of alternative trajectories in foreign markets (e.g. Andersen, 1997; Hedlund \& Kverneland, 1993; Oesterle, 1997; Turnbull \& Ellwood, 1986; Zander \& Zander, 1997). Yet more studies argue that the Uppsala model is timebound. The most common argument is that the model was formulated in the late 70s when the international business environment was less turbulent than today (Benito \& Grispund, 1992; Khurana \& Talbot, 1998). Finally, others have argued that the model is bound to the Swedish context and, as a result, is ill-equipped to explain the internationalisation processes of Polish (Fonfara \& Collins, 1990), Japanese (Banerji \& Sambharya, 1996), South Korean (Oh et al., 1998) and Brazilian (Rocha et al., 2002) firms.

More importantly, from the perspective of this article, some scholars have suggested that the Uppsala model explains well the trajectory of the so-called early starters (Johanson \& Mattsson, 1988), i.e., novices in international markets, but is less suited for explaining the internationalisation process of larger and more experienced firms such as the MNCs (Birkinshaw \& Hood, 1998) ${ }^{(3)}$. Forsgren (2002), in particular, emphasises that the explanatory power of the model is reduced for firms that have spread operations across countries. 
MNCs are not only concerned with the penetration and extension of operations in a particular foreign market (Johanson \& Mattsson, 1998). An important dimension of their internationalisation processes is related to a simultaneous intraand inter-firm flow of knowledge (Gupta \& Govindarajan, 1991). This means that knowledge in the internationalisation of MNCs can be created through relationships other than the focal subsidiary and external actors embedded in the host country. For example, it can be developed by the interplay amongst subsidiary units. In this case, the evolution of a particular subsidiary is dependent upon knowledge developed together with and/or transferred from sister subsidiaries (Lord \& Ranft, 2000; Mudambi \& Navarra, 2004). In other words, knowledge evolves interactively within the MNC network. This interdependence signifies that knowledge in the internationalisation of MNCs can be generated, transferred and appropriated by various actors embedded in the MNC network (Loasby, 2002).

MNCs also appear to allocate time and managerial resources to exploit the benefits of multinationality, i.e., advantages realized through the coordination of subsidiary units (Kogut, 1990), which are usually grounded on the transfer of tacit and experiential knowledge across borders (Kogut \& Zander, 1993, 2003). This has led Mattsson (1998) to claim that international integration should be regarded as a third dimension of internationalisation processes. Johanson and Vahlne (1990) go further by suggesting that international integration may have a strong impact on the internationalisation of the firm. Due to the multiplicity of the interdependent spatial contexts in which MNCs operate, changes within the MNC network can originate in a particular context and be subsequently carried over to other contexts (Easton \& Lundgren, 1992). Therefore, it will be very difficult to predict the pattern of evolution of internationalisation processes for MNCs as they tend to be more complex and variable than the internationalisation of neophytes (Forsgren, 2002; Melin, 1992).

All in all, it appears that the internationalisation of MNCs falls outside the scope of the Uppsala model. As discussed earlier, although this boundary condition is acknowledged in the extant literature, empirical research says little concerning the pattern of evolution of the internationalisation processes of MNCs. In order to help fill this gap, in the next section we propose conceptualising MNCs as loosely coupled systems. In so doing, we suggest that, rather than a single internationalisation process, there may be a number of internationalisation processes within an MNC network (Holm et al., 1995). Even though these processes evolve in parallel, they can influence and be influenced by each other at critical junctures (Mahoney, 2000). In other words, these processes can be simultaneously independent and interdependent across various spatial and temporal contexts of the MNC network. 


\section{Internationalisation of MNCs as loosely Coupled Systems}

According to Johanson and Vahlne (1977, 1990, 2003), the Uppsala model regards the international firm as a loosely coupled system (henceforth LCS). Although this has remained an unquestionable metaphor for a long time, more recently Bjorkman and Forsgren (2000) have argued that, to some extent, the model violates key assumptions of the LCS perspective. Forsgren (2002) points out that the model works better if this perspective is replaced by a hierarchical view of the firm.

First, in a LCS the focus on the dyadic relationship between the headquarters (henceforth HQ) and the subsidiary unit is expanded to embrace a multitude of direct and indirect relationships embedded in various spatial contexts of the MNC network (Hedlund, 1986). Lateral relationships are, for instance, critical to understanding how MNCs are organised and evolve over time (Ghoshal \& Bartlett, 1990; Hedlund, 1993). Specifically, whereas in hierarchies the HQ controls and co-ordinates the internationalisation process, which is an idea implicitly espoused by the Uppsala model, in a MNC as a LCS the HQ does not necessarily have this prerogative (Birkinshaw, 1996, 1997). Powerful subsidiaries, i.e. units that control critical resources, may take on more responsibilities in the MNC network in which they are embedded by, for example, guiding the internationalisation process of sister subsidiaries (Forsgren \& Pahlberg, 1992). They may also be in charge of their own internationalisation process (Forsgren et al., 1992).

Secondly, the firm portrayed in the Uppsala model is a singular entity whose parts are undifferentiated (Lord \& Ranft, 2000). However, the LCS perspective offers a diametrically opposite view of MNCs, which are seen as highly differentiated systems that simultaneously and paradoxically contain elements that are "open and closed, indeterminate and rational, spontaneous and deliberate" (Orton \& Weick, 1990, p. 205). As a consequence, there may be distinct roles for the HQ and the subsidiary as well as amongst the subsidiaries (Bartlett \& Ghoshal, 1986). In addition, power is likely to be unevenly distributed in MNCs (Forsgren, 1989).

Thirdly, the Uppsala model is dependent on the interpretation of experiential knowledge and past outcomes of a stable middle management team of the firm (Bjorkman \& Forsgren, 2000) as there is no turnover of the staff in charge of each internationalisation process. This implies that there is a coincidence in the loci of knowledge, decision-making and implementation in the internationalisation of the firm (Birkinshaw, 1998; Forsgren, 2002). 
As mentioned earlier, in the LCS perspective, knowledge of internationalisation does not only rest upon the experience of the middle management team, but is also developed by a number of actors within the MNC network through mechanisms other than learning by doing. Thus the idea of a single and coherent interpretation of internationalisation by a stable team of individuals steering the process throughout is open to dispute. In a MNC as a LCS, the internationalisation process is likely to lead to distinct and possibly contradictory accounts reflecting knowledge of what is stored in the minds of those directly involved with internationalisation as well as of what is grounded in the collective memory of the firm.

With these implications in mind, the LCS perspective leaves room to consider two dimensions that are, in our view, pivotal to addressing the internationalisation process of MNCs as LCSs: independence and interdependence (Orton \& Weick, 1990; Weick, 1995). Independence means that actors or units of a MNC are relatively autonomous to carry out activities that transcend the spatial context in which they are initially embedded. For example, Forsgren et al. (1992) coined the term 'internationalisation of the second degree' to illustrate the process through which the subsidiary follows its own internationalisation process by exporting and/or allocating resources to third countries. Birkinshaw (1997) provides examples of subsidiary initiatives in third countries, such as world product mandates. Therefore independence implies that a number of parallel internationalisation processes may occur within the MNC network with and, more importantly, without the acquiescence of the HQ.

In turn, interdependence means that these parallel internationalisation processes are contingent on each other. O'Donnell (2000, p. 530) defines international interdependence as the "condition to which one subsidiary or subunit of the MNC relies on another subunit's activities or inputs in order to perform its role effectively". Among other things, this means that the internationalisation process of an actor or unit of the MNC influences and/or is influenced by other internationalisation processes occurring within the said MNC network.

We argue that the interdependence of internationalisation processes is empirically more visible at critical junctures (Mahoney, 2000; Pierson, 2004), i.e., points in space and time in which these processes collide. This is relevant because important changes in the evolution of internationalisation processes can be manifested at these points. In the next section, we will look at changes in uniformity, direction and rhythm of internationalisation processes.

To sum up, the LCS perspective implies conceptualising MNCs as heterogeneous networks within which a number of independent and sometimes interdependent internationalisation processes co-evolve in various spatial and temporal contexts. Because of interdependencies between processes, it is 
expected that the internationalisation of MNCs eventually exhibits "a broader spectrum of internationalisation routes than the [Uppsala] model predicts" (Forsgren, 2002, p. 274).

\section{The Pattern of Evolution of MNCs' Internationalisation Processes: Uniformity, Direction AND Rhythm}

Before moving on, let us examine the term internationalisation for a moment. By internationalisation, we mean the extension of a firm's operations into foreign markets (Welch \& Luostarinen, 1988). In this article, the internationalisation of the firm is analysed on the basis of the framework developed by Araujo and Rezende (2003). Accordingly, intern modal changes. Whereas the mode of operation is characterised by the degree of localisation, externalisation and integration of activities (Jarillo \& Martinez, 1991), the relationships that are taken into account are those between the focal subsidiary and the HQ, external actors and sister subsidiaries.

Given these considerations, we put forward three dimensions that are likely to be influenced by the interdependence of the internationalisation processes of MNCs as LCSs: uniformity, direction and rhythm. It is our contention that in these firms the interdependence of internationalisation processes is negatively related to their uniformity, direction and rhythm (Figure 1).

\section{Figure 1: Interdependence of Internationalisation Processes and Uniformity, Direction and Rhythm}

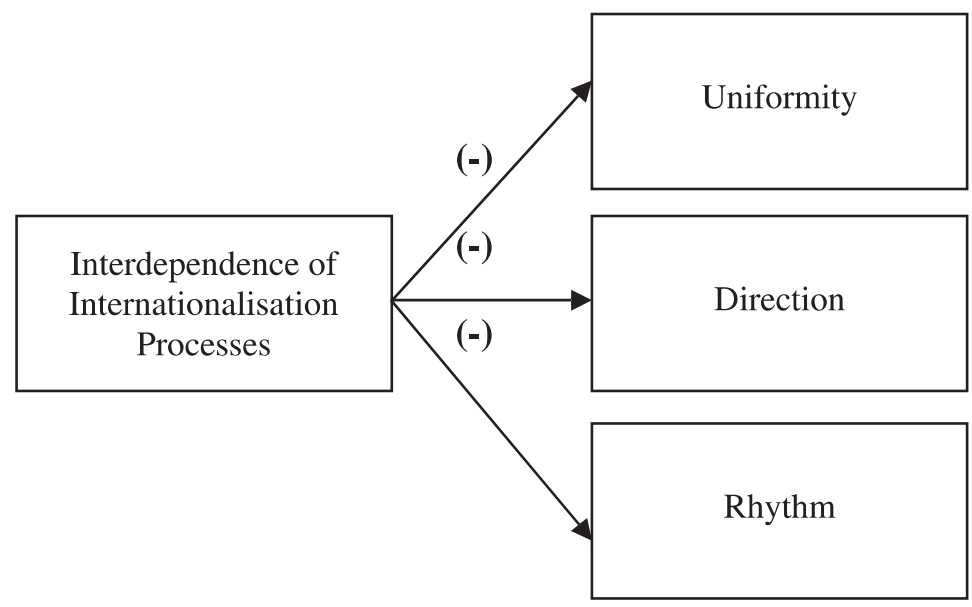




\section{Uniformity}

The pattern of evolution of the internationalisation processes of MNCs may differ in relation to uniformity. This dimension is concerned with the degree of regularity of internationalisation processes over time. A high uniform internationalisation process tends not to have abrupt variations in modal changes. Or, alternatively, the higher the uniformity, the shorter the breadth of variation in modal changes. For example, Figure 2a depicts internationalisation processes characterised by a high degree of uniformity. In contrast, the internationalisation process shown in Figure $2 \mathrm{~b}$ is less regular because the mode of operation is changed abruptly twice.

\section{Figure 2a: Uniformity of Internationalisation Processes: Examples of Higher Uniform Processes}
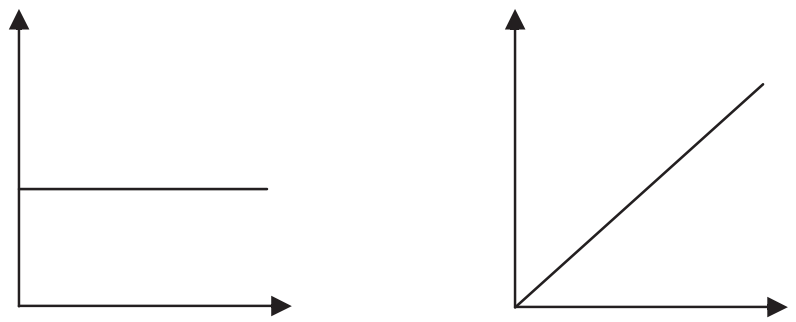

Figure 2b: Uniformity of Internationalisation Processes: Example of a Lower Uniform Process

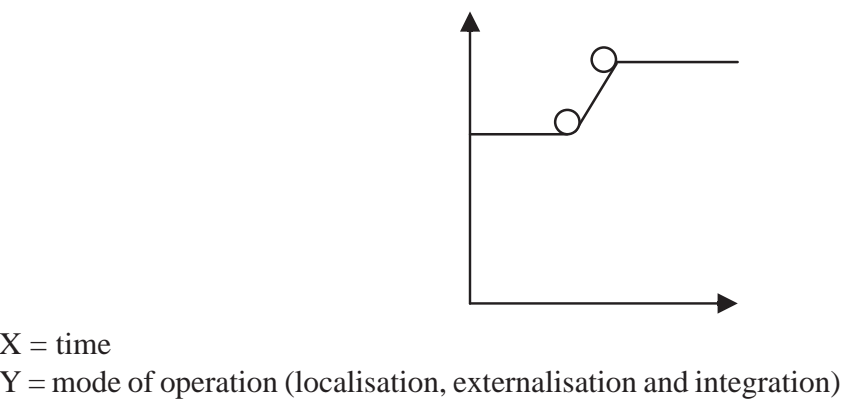

The Uppsala model envisages internationalisation processes that exhibit a high level of uniformity, such as the process depicted on the right hand side of Figure 2a. This reflects a gradual, stepwise process of resource commitment to a foreign market (Johanson \& Vahlne, 1977). However, the pattern of evolution of the internationalisation of MNCs as LCSs tends to be substantially 
different as it is likely to alternate between periods of gradualism and more discontinuous phases.

We suggest that variation in uniformity can be caused by the collision of a number of internationalisation processes that co-evolve in different spatial contexts within the MNC network. This implies that there is a relation between the interdependence of internationalisation processes within the MNC network and their uniformity. We suggest that the more interdependent an internationalisation process is in relation to other internationalisation processes coexisting in the same MNC network, the more vulnerable it is to changes originated in spatial contexts other than the focal host country. These changes have the causal power to introduce variation in the uniformity of internationalisation processes.

Hypothesis 1 - Other things being equal, the interdependence of internationalisation processes within a MNC network is negatively related to their uniformity.

\section{Direction}

Whereas uniformity corresponds to the degree of regularity of internationalisation processes over time, direction refers to the paths taken by a particular internationalisation process. The more an internationalisation process changes direction, the more it takes paths that are substantially different from the original path in terms of degree of localisation, externalisation and/or integration of activities.

Uniformity and direction are independent dimensions of the internationalisation processes of MNCs as LCSs. As discussed earlier, Figure 2b depicts an internationalisation process with a low level of uniformity because the mode of operation does not change gradually. In spite of this, it remains in the same direction, i.e., increasing levels of localisation, externalisation and/or integration of activities.

By contrast, changing direction in an internationalisation process implies altering the pattern of evolution in terms of the paths taken. This can be illustrated by Figure 3, which shows an internationalisation process that changes direction twice. Up to point a, the curve goes upward, but from point a to b, it takes the opposite direction. 


\section{Figure 3: Direction of Internationalisation Processes: Example of a Process that Changes Direction Twice}

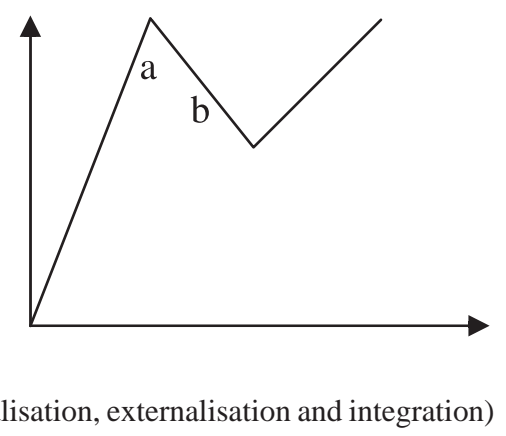

$\mathrm{X}=$ time

$\mathrm{Y}=$ mode of operation (localisation, externalisation and integration)

There is a coincidence of uniformity and direction in the internationalisation processes analysed in light of the Uppsala model. The model is built upon a highly uniform process that avoids changing direction. The initial pattern of the evolution of gradual resource commitment continues moving in the same direction over the years. In this sense, the Uppsala model leaves little room for other internationalisation paths such as de-internationalisation, partial withdrawals or reversals in commitment (Benito \& Welch, 1997).

On the contrary, we expect that the interdependence of internationalisation processes within MNCs affects their direction, i.e. the process is likely to change direction quite frequently, including more radical changes such as the exit from a particular foreign market. Rezende (2005) provides an example of a British MNC that evolved in the Brazilian market by simultaneously increasing the degree of localisation and decreasing the degree of externalisation of activities. This pattern of evolution was broken when it left the Brazilian market. Specifically, due to the interdependence between the units of the MNC of which it was part (changes were originated in the European market), the Brazilian subsidiary ceased its activities in Brazil.

While our first hypothesis suggests that the uniformity of internationalisation has to do with the interdependence of internationalisation processes within the MNC network, a similar reasoning applies to the direction of internationalisation processes. Changes originated elsewhere in the MNC network may drive one internationalisation process to take paths that do not bear the imprint of the earlier choices (Mahoney, 2000; Pierson, 2004). Therefore the higher the interdependence of internationalisation processes, the more they change direction. 
Hypothesis 2 - Other things being equal, the interdependence of internationalization processes within a MNC network is negatively related to their direction.

\section{Rhythm}

Rhythm is a dimension of internationalisation processes originally developed by Vermeulen and Barkema (2002) and refers to the intervals between the establishment of foreign subsidiaries. They suggest that firms following more rhythmic internationalisation processes tend to establish units in foreign markets at a more regular rate, such as one subsidiary per year. More rhythmic expansion programmes avoid the overload of managerial resources by creating room for better absorption of new knowledge of foreign markets.

Inspired by this discussion, we suggest that the rhythm of internationalisation processes can also be related to the intervals between modal changes regardless of the governance form selected. Thus, the more rhythmic an internationalisation process is, the more similar the intervals between modal changes are. For example, Figure 4 shows the rhythm of two different internationalisation processes. The process depicted on the left is more rhythmic whereas the one represented on the right side is characterised by uneven intervals between modal changes.

Figure 4: Rhythm in Internationalisation Processes: Examples of Processes with Similar and Distinct Intervals between Modal Changes
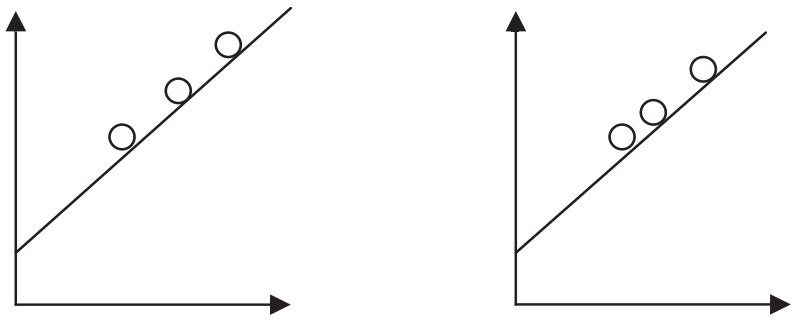

$X=$ time

$\mathrm{Y}=$ mode of operation (localisation, externalisation and integration)

Although the Uppsala model does not take into account the dimension of rhythm of internationalisation processes, we agree with Vermeulen and Barkema (2002) that rhythm is an important dimension of internationalisation processes of MNCs. Based on the arguments underpinning hypotheses 1 and 2, we propose that the interdependence of internationalisation processes within MNCs affects their rhythm. Specifically, changes originated in multiple spatial contexts within the 
MNC network are likely to disrupt more rhythmical internationalisation process. In this event, periods when the mode of operation is changed more regularly alternate with phases with no modal changes. Our final hypothesis posits a negative relationship between interdependence and rhythm of internationalisation processes.

Hypothesis 3 - Other things being equal, the interdependence of internationalisation processes within a MNC network is negatively related to their rhythm.

\section{Conclusions}

In this article we address the interdependence of internationalisation processes within the MNC network. Although scholars such as Johanson and Vahlne (1990) and Mattsson (1998) have claimed that interdependence between markets is a critical dimension of internationalisation processes, little research has examined this issue in detail.

The behavioural literature on internationalisation and, in particular, the Uppsala model, views the internationalisation process as independent, i.e., one internationalisation process would have little impact on another internationalisation process within the MNC network. To some extent, this approach reflects a hierarchical view of the firm in which the HQ co-ordinates and controls the development of the subsidiary units.

In this article, we have taken a different route. In order to understand the internationalisation of MNCs, we have attempted to combine the literature on internationalisation processes with the literature on MNCs and subsidiary development. Our starting point is that the conceptualisation of MNCs as LCSs provides a useful platform for addressing the issue of the independence and interdependence of internationalisation processes within MNCs. In terms of the model developed in this article, this means that a number of internationalisation processes co-evolve asymmetrically within the MNC network. At critical junctures, one internationalisation process can influence and be influenced by another internationalisation process and, as a result, its pattern of evolution will vary in terms of uniformity, direction and rhythm.

These results may have important theoretical implications for research on MNCs. They highlight the interdependence of internationalisation processes as a key mechanism in driving the development of MNCs. Accordingly, the internationalisation processes of MNCs are not only influenced by driving forces that solely operate in the geographical context where the processes are initially 
embedded. They can also be affected by a multitude of forces that are originally triggered in other spatial contexts within the MNC network, and which are transmitted to other spatial contexts through direct and indirect relationships between the HQ, external actors and subsidiary units.

This implies that the internationalisation of MNCs is not necessarily the sum of individual internationalisation processes embedded in distinct foreign markets. On the contrary, a more realistic picture of how MNCs evolve points to an intricate combination of independent, yet interdependent, internationalisation processes that take place in various spatial and temporal contexts. In short, the internationalisation of MNCs comprises numerous internationalisation processes following different sequences of modes of operation (Forsgren, 2002), including the step-by-step route suggested by the Uppsala model.

In suggesting that the interdependence of internationalisation is negatively related to uniformity, direction and rhythm, our research leaves some questions unanswered. For example, how do changes flow within the MNC network? What are the factors that affect the flow of these changes?

Closely related, more recently the international business literature has emphasised the issue of knowledge transfer within the MNC network (e.g. Blomstermo \& Choi, 2003; Gupta \& Govidarajan, 1991, 2000). We believe that the interdependence of internationalisation processes can affect the accumulation of knowledge at the level of the subsidiary unit as well as the development of inter-subsidiary knowledge. How is this influence manifested in terms of accumulation and/or transfer of knowledge? To what extent is local knowledge dissipated, devalued or bypassed by changes originated elsewhere in the MNC network?

Finally, the literature puts forward a number of typologies for classifying the architecture of MNCs as well as their subsidiaries. For example, Porter (1986) classifies MNCs according to the degree of co-ordination and configuration of activities. Gupta and Govidarajan (1991) use intra-corporate knowledge to distinguish types of subsidiaries. Following this line of research, we wonder to what extent the interdependence of internationalisation processes is contingent on the types of architecture of MNCs. For example, is interdependence likely to be more prevalent in a globally-oriented MNC? If so, to what extent is the internationalisation of a globally-oriented MNC more variable in terms of uniformity, direction and rhythm than the internationalisation of a locally-oriented MNC? Much work remains to be done in researching these topics.

\section{Artigo recebido em 04.07.2005. Aprovado em 07.10.2005.}




\section{Notes}

${ }^{1}$ An earlier version of this article was presented at XXVIII ENANPAD and awarded as the best article of the Strategic Management Division. We appreciate the comments of the conference participants and are also grateful to Angela Versiani, John Child and Luis Araujo for comments on earlier drafts. Special thanks are also due to Mats Forsgren for his insights and encouragement. Financial support from CAPES is gratefully acknowledged. The usual disclaimers apply.

${ }^{2}$ Originally, the Uppsala model views the internationalisation of the firm as resulting from knowledge developed between the HQ and the subsidiary unit (Johanson \& Vahlne, 1977). Later, the model was expanded to take into account the role of multilateral relations, that is to say, knowledge developed through inter-firm relationships (Johanson \& Vahlne, 1990).

${ }^{3}$ Research on Born Global challenges the idea that initially the firm accumulates capabilities in the domestic market to develop them subsequently in the international arena (e.g. Oviatt \& Mcdougalll, 1997; Sharma \& Blomstermo, 2003; Rocha et al., 2005). The main thrust of this body of research is that some firms establish operations in foreign markets from inception. As a result, they do not follow a gradual, stepwise internationalisation process. Research on International Entrepreneurship has reached similar conclusions (e.g. Jones \& Coviello, 2005; Zahra et al., 2005).

\section{REFERENCES}

Aaharoni, Y. (1966).

The foreign investment decision process. Boston: Graduate School of Business Administration Harvard University.

Andersen, O. (1993, Second Quarter). On the internationalization process of firms: a critical analysis. Journal of International Business Studies, 24(2), 209-233.

Andersen, O. (1997, Second Quarter). Internationalization and market entry mode: a review of theories and conceptual framework. Management International Review, 37(2), 27-42.

Araujo, L., \&

Rezende, S. (2003, December).

Path dependence, MNCs and the internationalisation process: a relational approach. International Business Review, 12(6), 719-737.
Banerji, K., \&

Sambharya, R. (1996, March).

Vertical keiretsu and international market entry: the case of the japanese automobile ancillary industry. Journal of International Business Studies, 27(1), 89-113.

Bartlett, C., \&

Ghoshal, S. (1986, November/December).

Tap your subsidiary for global reach.

Harvard Business Review, 86(6), 87-

94.

Bell, J., \&

Young, S. (1998).

Towards an integrative framework of the internationalization of the firm. In G. Hooley, R. Loveridge, \& D. Wilson (Eds.). Internationalization: process, context and markets (pp. 5-28). Hampshire: MacMillan Press Ltd. 
Benito, G., \&

Grispund, G. (1992, September).

Discrete rational location choices or a cultural learning process. Journal of International Business Studies, 24(3), 461-477.

Benito, G., \&

Welch, L. S. (1997).

De-Internationalization. Management International Review, 37(special issue), 7-25.

Birkinshaw, J. (1996, September).

How multinational subsidiary mandates are gained or lost. Journal of International Business Studies, 27(3), 467-495.

Birkinshaw, J. (1997, March).

Entrepreneurship in multinational corporations: the characteristics of subsidiaries initiatives. Strategic Management Journal, 18, pp. 207229.

Birkinshaw, J., \&

Hood, N. (1998).

Introduction and overview. In J. Birkinshaw \& N. Hood (Eds). Multinational Corporate Evolution and Subsidiary Development (pp.1-19). Great Britain: MacMillan Press Ltd.

Bjorkman, I., \&

Forsgren, M. (2000, Spring).

Nordic international research: a review of its development. International Studies of Management and Organization, 30(1), 6-25.

Blomstermo, A., \&

Choi, S. (2003).

Product complexity and knowledge translation in the internationalisation process of firms: an integrative model. In A. Blomstermo \& D. Sharma (Eds.). Learning in the Internationalisation Process of Firms (pp.175-190). Cheltenham: Edward Elgar.

Blomstermo, A., \&

Sharma, D. (2003).

Three decades of research on the internationalisation process of firms. In A. Blomstermo \& D. Sharma (Eds.). Learning in the Internationalisation Process of Firms (pp. 16-35). Cheltenham: Edward Elgar.

Buckley, P.,

Casson, M., \&

Gulamhussen, M. (2002).

Internationalisation - real options, knowledge management and the uppsala approach. In V. Havila, M. Forsgren, \& H. Hakansson (Eds.). Critical Perspectives on Internationalisation (pp. 229-262). Amsterdam: Pergamon.

Calof, J. (1995, October).

Internationalization behavior of smalland medium-sized South African enterprises. Journal of Small Business Management, 33(4), 71-79.

Calof, J., \&

Beamish, P. (1995, June).

Adapting to foreign markets: explaining internationalization. International Business Review, 4(2), 115-131.

Casson, M. (1994).

Internationalization as a learning process: a model of corporate growth and geographical diversification. In V. Balasubramanyam \& D. Sapsford (Eds.). The Economics of International Investment (pp. 14-46), England: Edward Elgar. 
Chang, S. (1995, April). International expansion strategy of japanese firms: capability building through sequential entry. Academy of Management Journal, 38(2), 383-407.

Chang, S., \&

Rosenzweig, P. (1998a).

Functional and line of business evolution processes in MNC subsidiaries: Sony in the USA, 19721995. In J. Birkinshaw \& N. Hood(Eds.). Multinational Corporate Evolution and Subsidiary Development (pp. 299332). Basingstoke: MacMillan.

Chang, S., \&

Rosenzweig, P. (1998b, November). Industry and regional patterns in sequential foreign market entry. Journal of Management Studies, 35(6), 797-822.

Chang, S., \&

Rosenzweig, P. (2001, August).

The choice of entry mode in sequential foreign direct investment. Strategic Management Journal, 22(8), 747-776.

Cohen, W., \&

Levinthal, D. (1990, March). Absorptive capacity: a new perspective on learning and innovation. Administrative Science Quarterly, 35(1), 128-152.

Cyert, R., \&

March, J. (1963).

A behavioral theory of the firm. Englewood Cliffs: Prentice-Hall, Inc.

Easton, G., \&

Lundgren, A. (1992).

Changes in industrial networks as flow through nodes. In B. Axelsson \& G. Easton (Eds.). Industrial networks: a new view of reality (pp. 89-104). London: Routledge.

Eriksson, K.,

Johanson, J.,

Hajkgard, A., \&

Sharma, D. (1997, June).

Experiential knowledge and cost in the internationalization process. Journal of International Business Studies, 28(2), 337-360.

Eriksson, K.,

Majkgard, A., \&

Sharma, D. (2000).

Path dependence and knowledge development in the internationalisation process. Management International Review, 40(1), 307-328.

Fonfara, K., \&

Collins, M. (1990).

The internationalisation of business in Poland. International Marketing Review, 7(4), 86-99.

Forsgren, M. (1989).

Managing the internationalization process: the swedish case. London: Routledge.

Forsgren, M. (2002, June).

The concept of learning in the uppsala internationalization process model: a critical review. International Business Review, 11(3), 257-277.

Forsgren, M.,

Holm, U., \&

Johanson. J. (1992).

Internationalization of the second degree: the emergence of europeanbased centres in swedish firms. In S. Young \& J. Hamit (Eds.). Europe and the Multinationals (pp. 235-253). Hants: Edward Elgar. 
Forsgren, M., \&

Pahlberg, C. (1992)

Subsidiary influence and autonomy in international firms. Scandinavian International Business Review, 1(3), 41-51.

Ghoshal, S., \&

Bartlett, C. (1990, October).

The multinational corporation as an interorganizational network. Academy of Management Review, 15(4), 603625.

Grael I., \&

Rocha, A. (1988).

O processo de internationalização de uma empresa. In A. Rocha (Org.). Gerência de Exportação no Brasil. São Paulo: Atlas.

Gupta, A., \&

Govindarajan, V. (1991, October).

Knowledge flows and the structure of control within multinational corporations. Academy of Management Review, 16(4), 768-792.

Hadjikhani, A., \&

Johanson, J. (2002, June).

Editorial special issue on the internationalization process of the firm. International Business Review, 11(3), 253-255.

Hadley, R., \&

Wilson, H. (2003, December).

The network model of internationalisation and experiential knowledge. International Business Review, 12(6), 697-717.

Havila, V.,

Forsgren, M., \&

Hakansson, H. (2002).

$$
\text { Critical perspectives on }
$$

internationalisation. Amsterdam: Pergamon.

Hedlund, G. (1993).

Assumptions of hierarchy and heterarchy, with applications to the management of the multinational corporation. In S. Ghoshal \& E. Westney (Eds.). Organization Theory and Multinational Corporation (pp.211-236), Hampshire: MacMillan Press Ltd.

Hedlund, G. (1986, Spring).

The hypermodern MNC - A heterarchy? Human Resource Management, 25(1), 9-35.

Hedlund, G., \&

Kverneland, A. (1993).

Are entry strategies for foreign markets changing? The case of swedish investment in Japan. In P. Buckley \& P. Ghauri (Eds.). The internationalization of the firm: a reader (pp. 106-123). Cambridge: The Academic Limited Press.

Hohenthal, J.,

Johanson, J., \&

Johanson, M. (2003, December).

Market discovery and the international expansion of the firm. International Business Review, 12(6), 659-672.

Holm, U.,

Johanson, J., \&

Thilenius, P. (1995, Spring/Summer).

Headquarters' Knowledge of subsidiary network context in the multinational corporation. International Studies of Management and Organization, 25(1-2), 97-119. 
Jarillo, J., \&

Martinez, J. (1991).

The international expansion of spanish firms: towards an integrative framework for international strategy. In L. G. Mattsson \& B. Stymne. (Eds.). Corporate and industry strategies for Europe (pp. 283-302). Amsterdam: Elsevier Science Publishers.

Johanson, J., \&

Vahlne, J. E. (1977, March).

The internationalization process of the firm: a model of knowledge development and increasing foreign market commitment. Journal of International Business Studies, 8(1), 23-32.

Johanson, J., \&

Vahlne, J. E. (1990).

The mechanism of internationalisation. International Marketing Review, 7(4), 11-24.

Johanson, J., \&

Vahlne, J. E. (2003).

Building a model of firm internationalisation. In A. Blomstermo \& D. Sharma (Eds.). Learning in the Internationalisation Process of Firms (pp. 3-15). Cheltenham: Edward Elgar.

Johanson, J., \&

Mattsson, L. G. (1988).

Internationalization in industrial system: a network approach. In N. Hood \& J. E. Vahlne. (Eds.). Strategies in global competition (pp.287-314). New York: Croom Helm.

Johanson, J., \&

Wiedersheim-Paul, F. (1975, October).

The internationalization of the firm: four swedish case. Journal of Management Studies, 22(4), 305-322.
Jones, M., \&

Coviello, N. (2005, May).

Internationalisation: conceptualising an entrepreneurial process in behaviour in time. Journal of International Business Studies, 36(3), 284-303.

Juul, M., \&

Walters, P. (1987, First Quarter).

The internationalization of norwegian firms: a study of the UK experience. Management International Review, 27(1), 9-25.

Khurana, A., \&

Talbot, B. (1998, May).

The internationalization process model through the lens of the global color picture tube industry. Journal of Operations Management, 16(2-3), 215-239.

Kogut, B. (1990).

International sequential advantages and network flexibility. In C. Bartlett, Y. Doz \& G. Hedlund (Eds.). Managing the global firm (pp. 47-68). London: Routledge.

Kogut, B., \&

Zander, U. (1993, December).

Knowledge of the firm and the evolutionary theory of the multinational corporation. Journal of International Business Studies, 24(4), 625-645.

Kogut, B., \&

Zander, U. (2003, November).

A memoir and reflection: knowledge and an evolutionary theory of the multinational firm 10 years later. Journal of International Business Studies, 34(6), 505-515. 
Loasby, B. (2002, December).

The evolution of knowledge: beyond the biological model. Research Policy, 31(8-9), 1227-1239.

Lord, M., \&

Ranft, A. (2000, December).

Organizational learning about new international markets: exploring the internal transfer of local market knowledge. Journal of International Business Studies, 31(4), 573-589.

Mahoney, J. (2000, August).

Path dependence in historical sociology. Theory and Society, 29(4), 507-548.

Mattsson, L.G. (1998).

Dynamics of overlapping networks and strategic actions by the international firm. In A. Chandler, P. Hagstrom, \& O. Solvell (Eds.). The dynamic firm: the role of technology, strategy, organization, and regions (pp. 242-259). Oxford: Oxford University Press.

Melin, L. (1992, January).

Internationalization as a strategy process. Strategic Management Journal, 13(1), 99-118.

Mudambi, R., \&

Navarra, P. (2004, September).

Is knowledge power? Knowledge flows, subsidiary power and rentseeking within MNCs. Journal of International Business Studies, 35(5), 385-406.

O’Donnell, S. (2000, May).

Managing foreign subsidiaries: agents of headquarters or an interdependent network. Strategic Management Journal, 21(5), 525-623.
Oesterle, M. J. (1997).

Time-span until internationalization foreign market entry as a built-in mechanism of innovations. Management International Review, 37(2), 125-149.

Oh, D.,

Choui, C., \&

Choi, E. (1998, October).

The globalization strategy of daewoo motor company. Asia Pacific Journal of Management, 15(2), 185-203.

Orton, D., \&

Weick, K. (1990, April).

Loosely coupled systems: a reconceptualization. Academy of Management Review, 15(2), 203-224.

Oviatt, B., \&

McDougall, P. (1997).

Challenges for internationalization process theory: the case of international new ventures. Management International Review, 37(2), 85-99.

Pedersen, T., \&

Petersen, B. (1998, October).

Explaining gradually increasing resource commitment to a foreign market. International Business Review, 7(5), 483-501.

Petersen, B., \&

Pedersen, T. (1997).

Twenty years after - support and critique of the uppsala internationalisation model. In I. Bjorkman \& M. Forsgren (Eds.). The nature of the international firm: nordic contribution to international business research (pp.117-132). Copenhagen: Copenhagen Business School Press. 
Pierson, P. (2004).

Politics in time: history, institutions and social analysis. USA: Princeton University Press.

Porter, M.E. (1986).

Competition in global industries: a conceptual framework. In M. E. Porter (Ed.). Competition in global industries (pp. 15-60). Boston, Mass: Harvard Business School Press.

Rezende, S. (2005).

Path Dependence e Internacionalização: o caso de uma empresa britânica no Brasil. In C. Hemais (Org). Os desafios dos mercados externos: teoria e prática na internacionalização da firma. Rio de Janeiro: Mauad.

Rocha, A.,

Blundi, M., \&

Dias, V. (2002).

$\mathrm{O}$ que aconteceu às empresas brasileiras exportadores da década de 70. In A. Rocha (Org.). A internationalização das empresas brasileiras: estudos de gestão internacional (pp. 63-84). Rio de Janeiro: Mauad.

Rocha, A.,

Melo, R.,

Dib, L., \&

Maculan, A. (in press).

Empresas que nascem globais: estudo de casos no setor de software In C. Hemais (Org). Os desafios dos mercados externos: teoria e prática na internacionalização da firma. Rio de Janeiro: Mauad.
Sharma, D., \&

Blomstermo, A. (2003, December).

The internationalization process of born globals: a network view. International Business Review, 12(6), 739-753.

Sullivan, D., \&

Bauerschmidt, A. (1990).

Incremental internationalization: a test of Johanson and Vahlne's thesis. Management International Review, 30(1), 19-30.

Turnbull, P., \&

Ellwood, S. (1986).

Internationalisation in the information technology industry. In P. Turnbull \& S. Paliwoda (Eds.). Research in international marketing (pp.162-192). Great Britain: Croom Helm.

Vermeulen, F., \&

Barkema, H. (2002, July).

Pace, rhythm and scope: process dependence in building a profitable multinational corporation. Strategic Management Journal, 23(7), 637-653.

Weick, K. (1995).

The social psychology of organizing (2nd ed.). New York,USA: AddisonWesley Pub.

Welch, L., \&

Luostarinen, R. (1988).

Internationalization: the evolution of a concept. Journal of General Management, 14(2), 34-55. 
Zahra, S.,

Korri, J., \&

Yu, J. (2005, April).

Cognition and international entrepreneurship: implications for research on international opportunity recognition and exploitation. International Business Review, 14(2), 129-146.
Zander, I., \&

Zander, U. (1997).

The oscillating multinational firm: alfa laval in the period 1980-1990. In I. Bjorkman \& M. Forsgren, (Eds.). The nature of the international firm: nordic contribution to international business research (pp. 89-115), Copenhagen: Copenhagen Business School Press. 